\title{
Jute-Boy at the Naturalization Derby
}

In the Chevy-sack, mottled and sharp: lean boy, to the ride.

Did you draw out your Hoo-Doo literature, the bone-for-itself?

Remember the riff bone, the one from the goddess-shank?

And the giraffe frame, the self-portrait, longing \& philosophicalwas that you, in Low Tucson, hoisting another flame?

Stole it? You did. In your reflex for passion, in your arsonist lazy fourth eye, the one next to the ear.

Eye\#1: for the Jute-Border tragedies, so buoyant:

this is how you measured your exile, nervous \& joyous.

Eye\#2: for the Ocelot cut-man you smuggled into your existence:

this is how you rose up and struck down your torturers.

Eye\#3: for the drowsy leaf eater, so polite in his self-abuse:

this is how you returned, to your tiny womb voice-victorious.

Eye\#4: this da Rice Warrior, can't see, but it there:

$O$, this-your language, in gestation; the last flight

shoot up, from your raw Motherland.

We note

your animal laboratory: one treasured police-dog leg, sprawled one parakeet vest, two coyote tracks-to cover up your migrant tardiness into bone-being. How you raced the tyrants, their feathers $\&$ spelled forgiveness, then genocide. But, the enemy stands before you. Can you identify? Let's leave the question open. 